\title{
Trade and Wages: A Malign Relationship?
}

\author{
by \\ Jagdish Bhagwati, Columbia University \\ October 1995 \\ 1994-95 Discussion Paper Series No. 761
}


Revised: October 1995

\title{
Trade and Wages: A Malign Relationship?
}

\author{
Jagdish Bhagwati \\ Arthur Lehman Professor of Economics \& \\ Professor of Political Science \\ Columbia University
}

Thanks are due to Manmohan Agarwal, Don Davis, Vivek Dehejia, Bill Dickens, Robert Feenstra, Marvin Kosters, Robert Lawrence, Ed Leamer, Jacob Mincer, Arvind Panagariya, T.N.Srinivasan and Martin Wolf for helpful conversations. Susan Collins deserves special thanks for many careful and constructive suggestions. 
The experience of decline in real wages of the unskilled workers during the 1980s in the United States, and the increase instead in their unemployment in Europe (due to the comparative inflexibility of their labour markets vis-a-vis those of the United States) ${ }^{1}$, has prompted a search for possible explanations. This search has become more acute with the evidence that the adverse trend for the unskilled has not been mitigated during the 1990 s to date.

Besides, the political leadership in both the the United States and the European Union has become more alert to the potential explosiveness of the issue. Thus, President Clinton, at a White House ceremony to gather support for the Uruguay Round ratification that week by Congress, focused just on this issue, categorically claiming that while Americans were worried about the effects of trade on their wages and jobs, trade was "not the cause but rather the solution" to their problems, indeed "the only solution". This was great politics, of course but, as the disagreements among economists in this volume suggest, not necessarily great economics as well.

Of course, the President, like Jacques Delors and others in Europe who fear competition from the "Asiatic ants", was speaking to the favoured explanation, indeed the haunting fear, of the unions and of many policymakers that international trade is a principal source of the pressures that translate into wage decline and/or unemployment of the unskilled. As Bhagwati and Dehejia (1994) put it: "Is Marx Striking Again?" . Perhaps we should have added: "with the aid of Samuelson" since, as stated below and now widely agreed, the principal reason to think that trade may be harming real wages of the unskilled is the early postwar work of Paul Samueison (1948)(1949) on Factor Price Equalization and, more directly, on the

\footnotetext{
'Note that this contrast between the US and Europe is just that, and is supposed to explain only the differential impact of technical change, trade etc. on wages in one country and on unemployment in the other. This labour-market explanation is almost a cliche by now, having been propounded by virtually every economist who has spoken on the issue in the last several years. Among the more recent writings on the subject are popular pieces by myself, Krugman and many others.
} 
Stolper-Samuelson (1941) theorem that bears immediately on the issue at hand. $^{2}$

I have earlier examined the question of trade explanations in Bhagwati (1991), and then again at great length in Bhagwati and Dehejia (1994). ${ }^{3} \quad$ My conclusion was that the trade explanation is exceptionally weak for the 1980s, and that there are good theoretical and empirical reasons why trade did not cause the adverse impact one might fear.

Here, I recapitulate, elaborate and evaluate the main linkages that have been now advanced between trade and real wages, extending the argumentation well beyond that in Bhagwati and Dehejia (1994), originally finished in mid-1993, in light of further empirical research and theoretical reflections that have emerged since then. The two papers thus are best read together and in the sequence in which they were written.

\section{I: Clarifications and Caveats}

At the outset, let me make a few clarifications and state a few caveats.

1. As Deardorff and Hakura (1994) in the Bhagwati-Kosters (1994) book have pointed out, it is necessary to be clear about the theoretical question which one is asking. In particular, let me note two different questions, of which the first is the one that I address in this paper.

Question 1: Will the freeing of trade, or an exogenous change abroad ${ }^{4}$, adversely affect the real wages of our unskilled? The empirical counterpart of this question, of course, is whether this has happened during and since the 1980 s.

Question 2: If domestic technical change is driving down the real wages

\footnotetext{
${ }^{2}$ Strictly speaking, the Stolper-Samuelson argument relates the decline in real wages of the unskilled to decline in the relative price of unskilled labour-intensive products. The factor price equalization argument, centrally related to the Heckscher-Ohlin theory, links the decline in the relative price of unskilled-labour-intensive goods to free trade with unskilled-labourabundant countries.

${ }^{3}$ Also, added insights may be found in Bhagwati (1994) (1995a)(1995b).

4 Such an exogenous change abroad would, generally speaking, shift the foreign offer curve facing us and hence the equilibrium terms of trade and therefore the factor rewards that are to be explained.
} 
of our unskilled, would the adverse effect on real wages be dampened or amplified if the economy was characterized by free trade rather than by protection?

It is clear that the former is the policy question that we are asking today. Thus, the question during the NAFTA debate was whether freer trade with Mexico would adversely affect the wages of the unskilled in the United States. When we look at the 1980 s experience, again we seek to know whether the emergence of developing countries in world trade, with or without rich-country liberalization, has done damage to the real wages of the unskilled in these rich countries.

2. The key point to bear in mind in any event is that, if we are to assert that the emergence of the poor countries in world trade is the cause of the declining real wages of the unskilled in the rich countries, then the intermediating mechanism in conventional general-equilibrium price theory models has to be, as argued in the analysis immediately below in Section II.1, a decline in the relative prices of the unskilled-labour-intenstive importables. If the goods prices have not changed as required, then it is not possible to sustain logically the argument that trade with the poor countries is the cause of the phenomenon we seek to explain.

Keeping in view what I discuss immediately below, this appears to me to be the case especially with arguments in the United States such as that the trade deficit in the 1980s must have had an impact on real wages because we have a good correlation between its size and the real wage decline and because imports are unskilled-labour-intensive. But the explanation is not compelling unless it is shown at the same time that the transfer has been attended by a decline in the (relative) prices of the unskilled-labour-intensive goods: an intermediating step in formal analysis, without which we cannot get from the alleged cause to the observed effect. The required decline in the relevant goods prices cannot simply be assumed, implicitly or explicitly, as having necessarily happened!

As demonstrated in Figure 1, it is perfectly possible for an inward or 


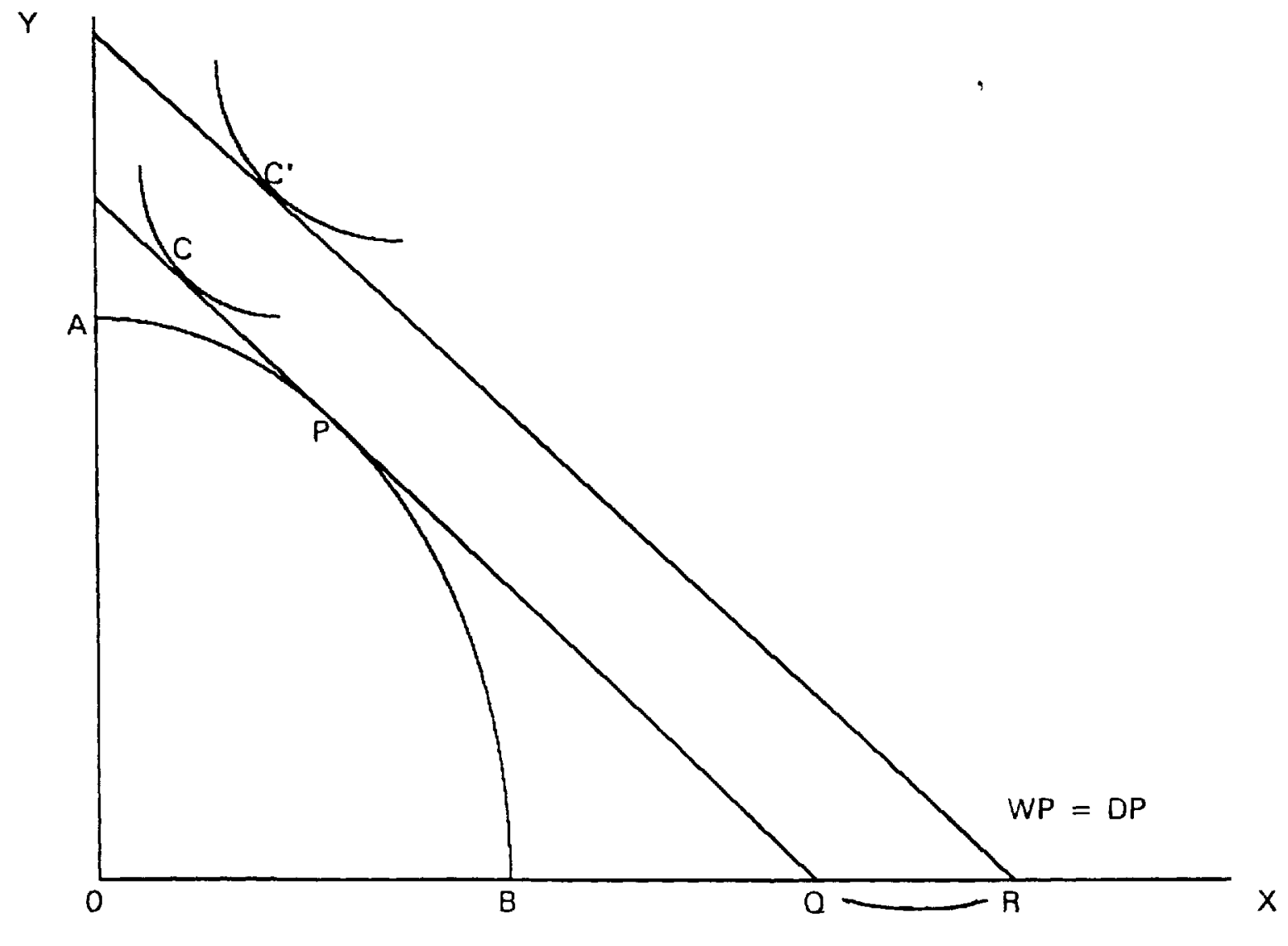

Deficit or Transfer

FIGURE 1 
outward transfer (i.e. a trade deficit or surplus) to have no impact at all on the terms of trade and hence no impact on real wages. ${ }^{5}$ There, $A B$ is the production possibility curve defined over traded goods $X$ and $Y$ is $A B$, the given world prices, equal to domestic prices under assumed free trade, are given by $Q R$ which determines domestic production at $P$ and national income, measured in good $X$, at $O Q$. Consumption then is at $C$. Assume now an inward transfer, equal to the trade deficit, of $Q R$. Added to the national income $O Q$, the transfer implies that the national expenditure now has increased from OQ to OR. At the given goods prices, it then leads to consumption at C'. Note that the absorption of the transfer QR has led (by assumption, of course) to no change in the goods price ratio $Q R$. Hence, there is no change in factor prices either (since, as argued below, the two are related, given technology, as shown by Paul Samuelson). Neither the trade deficit, nor increase therein, nor the associated increase in imports (whether unskilled-labour-intensive or not) has any impact whatsoever on the real wages of productive factors in this construct.

Indeed, as Deardorff and Hakura (1994) point out, the problem with many of the empirical studies of the relationship between trade and wages, including the most-cited ones, is that the relationships estimated between alleged causes and effects have not been grounded in well-specified models whose validity is then tested as it should be Thus, as I argue below, the factor-content calculations for the US which were held to show the adverse impact were not undertaken in the context of a clear model which would have enabled the investigators to see immediately that they should also test to see whether the goods prices behaved in the manner required by their inference. Hence, I agree with these authors that many of the current empirical studies are often tantalizing but leave one with no plausible conclusions. ${ }^{6}$

\footnotetext{
${ }^{5}$ Of course, there are numerous ways in which transfers can affect goods prices (i.e. the terms of trade): just see any graduate-level textbook such as Bhagwati and Srinivasan (1983, Chapter 12). The point in the text is that they need not, and any analysis that assumes that they must have (and that too in a particular direction) just because real wages of the unskilled fell and imports are unskilled-labour-intensive, is not acceptable.

${ }^{6}$ My critique of the Borjas-Ramey (1994) paper in Section Il.1 below is similar in spirit.
} 


\section{II: Alternative Theoretical Approaches}

I now distinguish among several theoretical approaches that can be taken to the problem, several to be found in the literature to date, probing them in some depth both from the analytical viewpoint and also in regard to their consonance with the facts as I see them.

1. Prices of Unskilled-labour-intensive Goods have fallen and caused the Real Wages of such Labour to fall, in turn: Economywide, North-South (StolperSamuelson) Explanation

Most economists' favorite explanation has been that increased trade with the South (i.e. poor countries) has led to the fall in the real wages of the unskilled (Lu) in the North (i.e. rich countries).

In essence, the argument must proceed as follows, though it is only implicit in many of the writings on the problem. Thus, consider two polar cases, each in turn. First, consider the case where the primary change comes from the South liberalizing trade or experiencing trade-expanding growth. Next, consider the case where the primary change comes instead from the North liberalizing its trade.

Figure 2 considers the first case, where the change comes from the South. The initial offer curve of the South, offering Lu-intensive exports, is S. It intersects with the offer curve of the North which exports skilled labour (LS)-intensive goods. OF would then be the world terms of trade (and hence the domestic goods prices in the North and the South as well if they had free trade). Now, assume that the South's offer curve expands to $S^{\prime}$ and the world terms of trade shift to OF'. This means that the world price of Lu-intensive goods has fallen. This, in turn, means that in the "passive" North the domestic prices of these goods would have fallen too.

Figure 3 shows the other polar case where the removal or reduction of North's own tariffs is the initiating change. Here, the offer curve of the North shifts 
$6(a)$

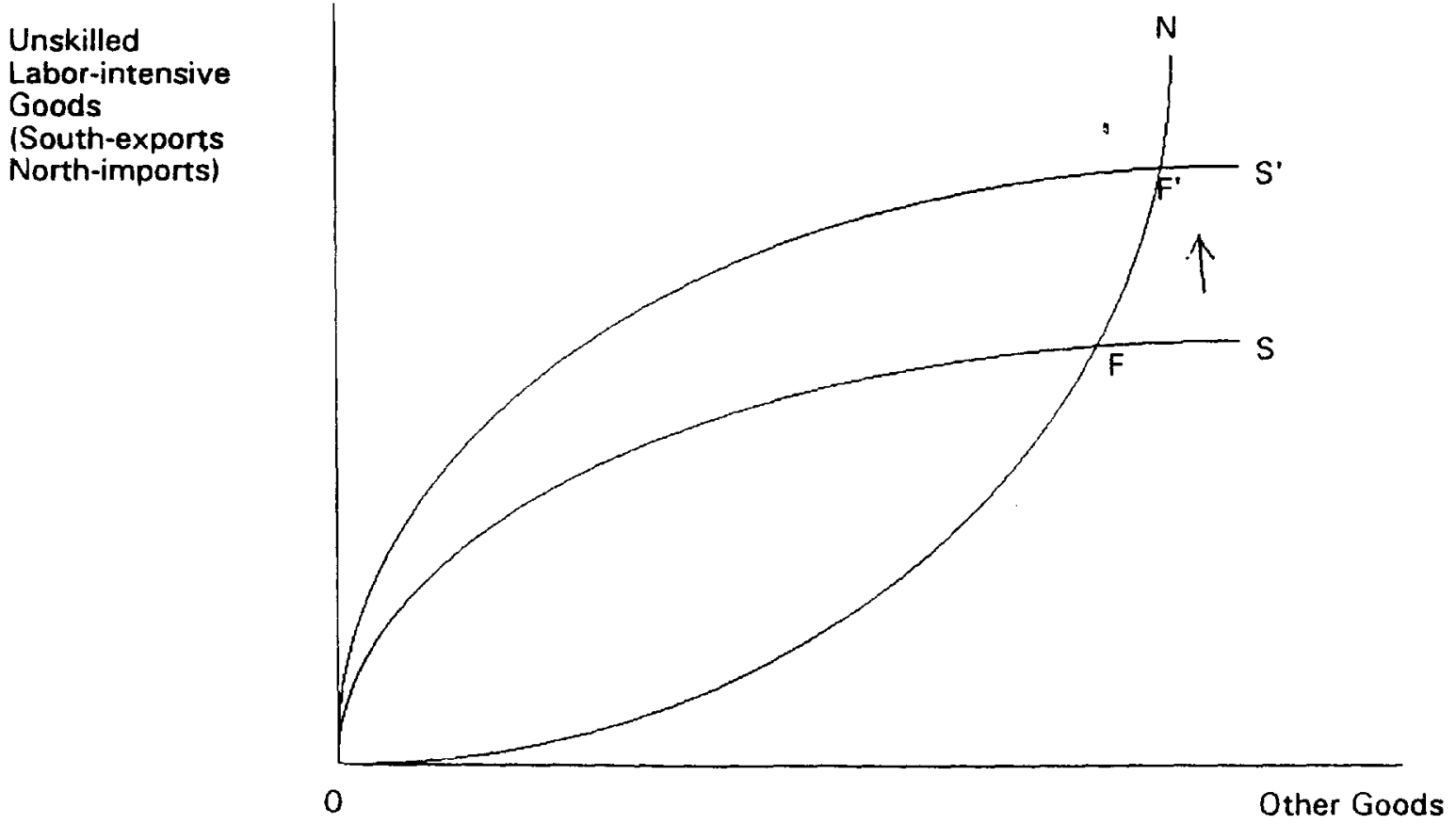

FIGURE 2 


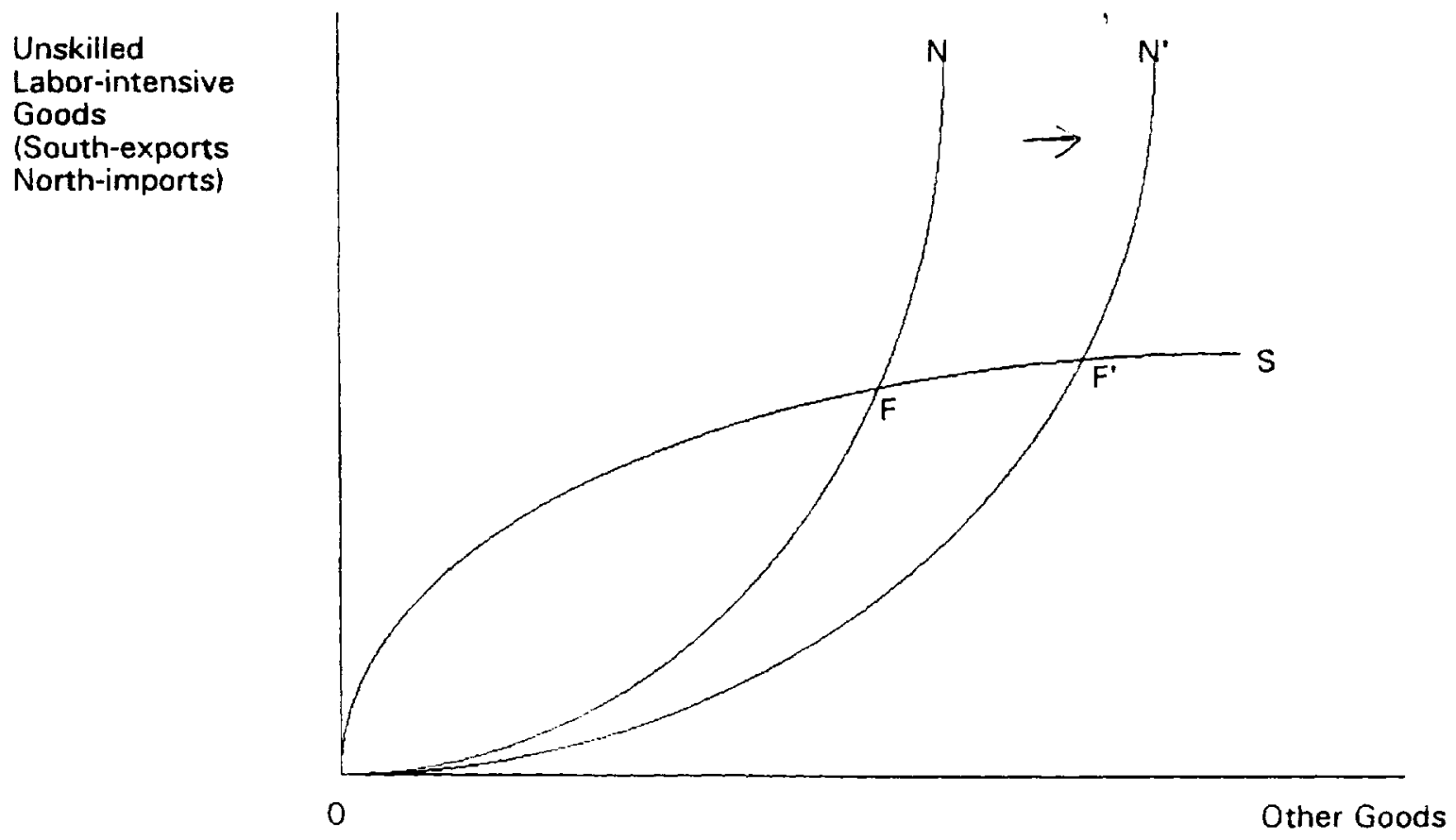

FIGURE 3 
from $\mathrm{N}$ to $\mathrm{N}^{\prime}$. The world terms of trade increase in favour of the Lu-intensive goods from OF to OF', instead of falling. But, since tariffs in the North have fallen, their domestic prices will fall (except in the paradoxical "Metzler" case where the terms of trade worsen by more than the tariffs fall).

In both cases, the effect would be to reduce the domestic prices of the Luintensive goods in the North. From there, the argument proceeds by deducing (with Stolper and Samuelson, as discussed below)) that the real wages of Lu must therefore fall. The critical element then is that the domestic prices of Lu-intensive goods fall in the North, not that their world prices do. Also, as in the first case, this can be a consequence, not of liberalization by the North, but of trade liberalization by the South or, even more tellingly, of simple trade-expanding growth by the South. ${ }^{7}$ Hence, the concern with trade with the poor countries as driving down the real wages of the unskilled in the rich countries is one that can arise, not only in the context of liberalizing trade with the South as in NAFTA, but also in the context of the expansion of such trade at any given level of trade barriers.

\section{Goods Prices and Factor Prices}

A critical intermediating step for both cases leading to a fall in the real wages of the unskilled in the North remains, however, that the domestic prices of the goods using unskilled labour should have fallen, as I first noted in 1990 when encountering the Borjas-Freeman-Katz paper (1991) in draft. ${ }^{8}$ It argued that trade was the cause of the decline in real wages but had not examined the behavior of goods prices [see the detailed critique in Bhagwati (1991a) (1991b), and subsequently in Bhagwati and Dehejia (1994)].

Thus, in general equilibrium we have in Figure 4 the familiar Samuelson relationship between goods prices (Px/Py) and factor prices or the "wage differential" (WuMs) in the right quadrant, and the Stolper-Samuelson relationship

\footnotetext{
${ }^{7}$ As we know from the massive trade-and-growth literature inspired by Harry Johnson in the 1960 s, growth can also be trade-reducing, at constant goods prices. My own priors are that this is not likely.

' I and Richard Freeman were both spending a year at the Russell Sage Foundation in New York, and the Borjas-Freeman-Katz paper was mentioned to me by Eric Wanner, President of the Foundation, over lunch in November 1990 and then given to me by Freeman in draft. I had been working at the time on a long essay on the relationship between Free Trade and Free Immigration in theory and in history, which turned eventually into Bhagwati (1991a).
} 
$7(a)$

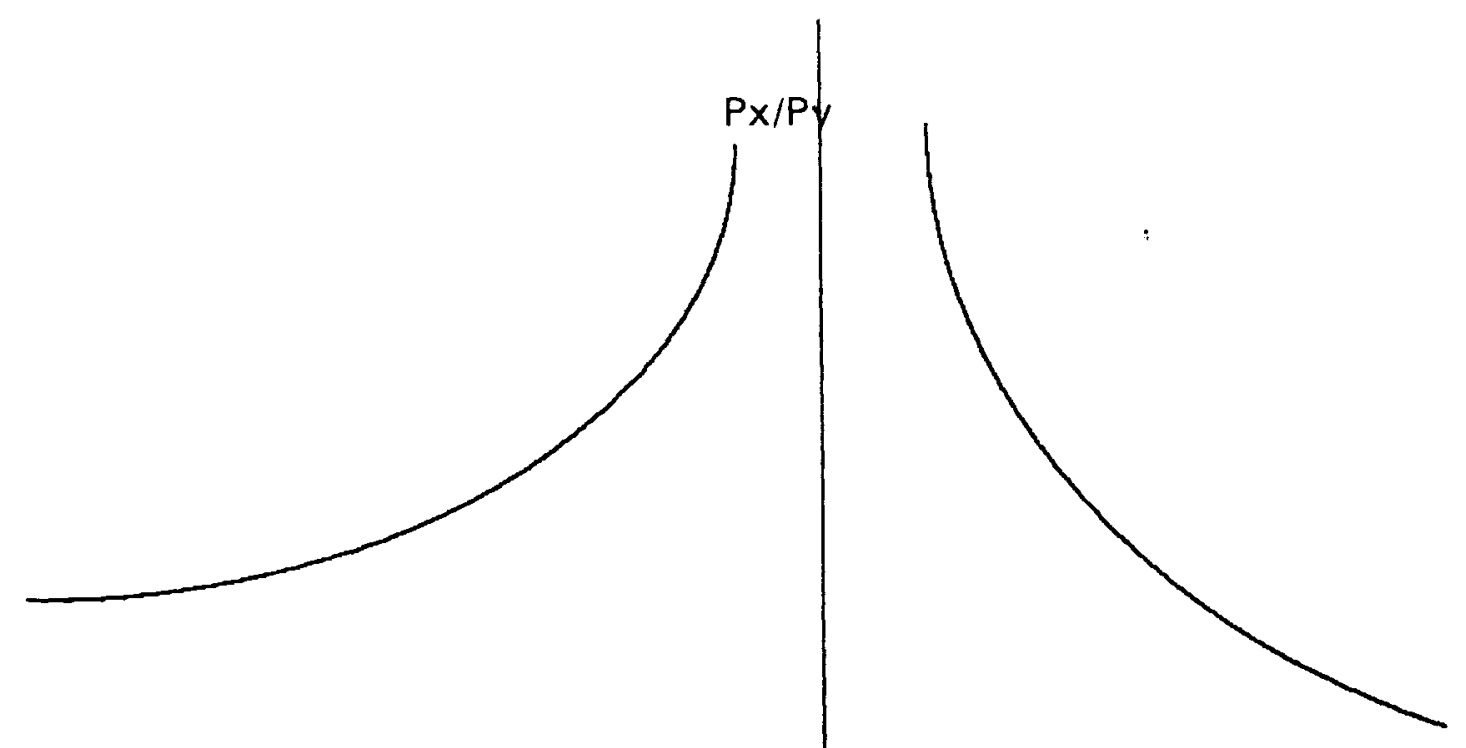

Real Wage of Unskilled Labor

FIGURE 4 
between the goods prices and the real wage of unskilled labour in the left quadrant (assuming, as explained below, that the economy is incompletely specialized in production). Each half of Figure 4, while familiar to students of trade theory, can be intuitively explained as follows.

The Samuelson half of the diagram follows from the convexity of $X$ and $Y$ isoquants, cost-minimization and the assumption that, at every factor price ratio imaginable, $X$ is Ls-intensive and $Y$ is Lu-intensive. ${ }^{9}$ Then, it is quite intuitive that, if unskilled labour, $L u$, becomes more expensive (i.e. one goes further down the horizontal axis marked WuMs), the price of the good using Lu intensively, i.e. good $\mathrm{Y}$, will rise, so that Px/Py will fall, pushing the curve down the vertical axis. Hence the curve tracing the relationship between Px/Py and Wu/Ws is monotonically falling from left to right.

The Stolper-Samuelson half of the diagram will be better understood after the discussion of Figures 5 and 6 below. But its essence can be understood by noting that the real wage of a productive factor in terms of a good, in competitive equilibrium, is nothing other than the marginal physical product of that factor in producing that good. When WuMS falls, the factor proportions U/S rise in each good's production and therefore the marginal physical product of unskilled labour, $U$, falls in terms of every good and therefore unambiguously regardless of what the factor consumes. ${ }^{10}$ This means that, as the left-hand-side Stolper-Samuelson half of Figure 4 shows, the real wage of unskilled labour also falls unambiguously as WuMs falls (and Px/Py rises in the Samuelson half of Figure 4).

Evidently, then, the real wage of the unskilled cannot fall unless the relative price of the good which is intensively using unskilled labour has fallen. Note that, as I argue below, this analytical necessity has nothing to do with what happens to quantities (of imports, production, consumption et.al.)

Having then examined the terms of trade data for US exports and imports of

\footnotetext{
${ }^{3}$ I.e. the factor-intensity ranking of the two goods is invariant to changes in the factor price ratio. When it is not, the curve in the Samuelson half of the diagram will curl back on itself: this is the case where factor intensity rankings are "reversible" and the unique relationship between goods and factor prices breaks down.

${ }^{10}$ Note that I use the phrase "in every good". This presupposes that every good is being produced in equilibrium. When the economy is completely specialized, the argument breaks down: instead of the real wage of one factor falling and the other correspondingly rising, both factors can improve their real wages, as argued later in the text.
} 
manufactures and finding that they showed a slight rise in the relative prices of imports, I conjectured (1991a) that the domestic goods prices of the unskilledlabour-intensive goods may have actually risen, rather than fallen as required by their conclusion. If so, the influential Borjas-Freeman-Katz study was flawed, not merely in its analytical methodology which failed to note the key role of change in goods prices in the argumentation, but (I feared) also in its empirical conclusion linking real wage decline to trade (in the Stolper-Samuelson fashion).

The detailed and careful empirical investigation by Lawrence and Slaughter (1993) that followed my (1991a)(1991b) papers did confirm my conjecture for the US. The subsequent article by Sachs and Schatz (1994) in Brookings Papers appears to overturn the Lawrence-Slaughter findings. However, it does not do anything of the kind. At the outset, it relies on removing from the data set the prices of computers, a procedure that is not adequately defended by the authors. And, even then, the new data set yields a coefficient of the required sign that is both very small and statistically insignificant. "Some accounts by wellknown journalists in The Financial Times and The Economist, misled no doubt by a hasty reading of a lengthy manuscript and the assumption that publication is a guarantor of quality, have reported this finding without realizing that, while Noam Chomsky correctly argues that two negatives make a positive in every human language (while two positives do not make a negative in any), the two negatives of a small coefficient and a statistically insignificant one to boot, do not add up to a positive support for the contention at issue. ${ }^{12}$

Lawrence (1994) notes this and also reports that the goods price behavior in Germany and Japan, with and without computers, does not support the trade

"Thus, Sachs and Schatz estimate the following equation, dummying out for computers (p.38):

The change in price $=0.04-0.02$ low skill intensity -0.02 computer dummy, $\vec{R}=-0.03$ $(1.47) \quad(-0.62) \quad(-1.04)$

The parentheses under the coefficients represent $t$-statistics. Note that none of the variables are significant. The authors admit that these results are "less than robust" (p.36), while arguing that they are in the "right" direction. Actually, the estimates are unacceptable.

12 The latest victims were the excellent Financial Times journalists, Stephanie Flanders and Martin Wolf, a few months ago, prompting me to write a Letter to the Editor arguing that nothing of the sort claimed by the cited authors had been demonstrated by scholarly standards. 
explanation either. Besides, the shifts in factor ratios also do not support the explanation for the US data, according to Lawrence and others.

In short, the necessary empirical evidence on price behavior during the 1980 s for the absolutely critical element in this particular trade explanation is currently nonexistent, whereas the price evidence in the contrary direction seems to be quite robust indeed. ${ }^{13}$ Perhaps this Bhagwati-Lawrence-Slaughter conclusion will be overturned by further work; but as of now it seems to have survived scrutiny. Even the further empirical work on estimating goods prices for the United States, by Ed Leamer (1995), confirms that the 1980s are not characterized by the required behavior to get the Stolper-Samuelson argument off the ground..$^{14}$

\section{Goods Prices and Real Wages}

Besides, as noted in Bhagwati and Dehejia (1994), even if the goods prices were behaving as required, the conclusion that the result would be a decline in the real wage of unskilled labour requires added assumptions familiar to the students of the Stolper-Samuelson theorem, many of which can be violated in the real world. Let me now proceed to recount some of the main arguments which are pertinent here, recalling that the "core" Stolper-Samuelson theorem, in its simplest $2 \times 2$ version, says simply: the real wage of the factor employed intensively in the good whose price has fallen will also fall unequivocally, while (by the same logic) the other factor's real wage will rise unequivocally.

*This core proposition (as also the Factor Price Equalization theorem, of

\footnotetext{
${ }^{13}$ This is the crux of the scientific skepticism about the trade-hurts-wages argument today. It must be sharply distinguished from the unacceptable argument, apparently advanced by even eminent authors, that trade from developing countries is such a small proportion of total trade, or that the import ratio is so small, that we cannot have the tail wagging the dog. In economics, however, the tail does wag the dog: prices are determined at the margin. The volume of transactions has no intrinsic meaning in itself. Indeed, the mere threat of a transaction in an integrated market, without any transactions occurring, can change a price.

${ }^{14}$ Leamer finds that the prices did behave as required in the period prior to the 1980s. Could we then have a delayed impact on the real wage of unskilled labour during the 1980 s even though the 1980s prices behaved perversely? The trouble is that, if this idea is formalized, there is still no obvious relief. For, suppose we argue that it takes time for labour to move out of the adversely affected import-competing industries. Then, its real wage will decline even more precipitously in these industries right away, with the impact reducing as labour moves out of them into other industries. The impact on the average real wages for the entire economy could then well be for it to fall during the period prior to 1980 s and then to rise during the 1980s.
} 
course, which requires a unique relationship between goods and factor prices to deduce factor price equalization from goods price equalization) fails as soon as one gets complete specialization (i.e. nondiversification) in production: both factors will improve their real wages as goods prices change further, lifting both boats instead of sinking one as the other symmetrically rises. The goods prices may change sufficiently so as to have the lifting-all-boats effect outweigh the redistributive effect embodied in the Stolper-Samuelson argument, leaving both factors better off than before. I.e. even when the price of unskilled-labour-intensive imports has declined (as it appears to have not during the 1980s, as already discussed), the real wage of unskilled labour could have improved (if the goods price change was substantial enough to produce the nondiversification, i.e. specialization in production on one of the two goods, and a large-enough "liftingall-boats" effect).

To see this, consider Figures 5 and 6 . The real wage of unskilled labour, (in terms of a mix of both goods, $X$ and $Y$ ), is mapped out in these matching figures for different goods price-ratios $P x / P y$, given the supply of unskilled and skilled labour, assuming that good $X$ is Ls-intensive while good $Y$ is Lu-intensive. Two cases are distinguished: one is autarky, the other is free trade.

First, in Figure 5, assume autarky and lower $P x / P y$ continuously, taking equilibrium production from $D$ to $C$. Since good $X$ is assumed to be intensive in the use of skilled labour, Ls, the (relative) factor price of unskilled labour (i.e. WuMs) rises, and that of skilled labour falls, as Px/Py falls successively and takes the economy's production from $D$ to $C$ : this is seen readily from the Samuelson half of Figure 4. As discussed by reference to Figure 4, then the real wage of unskilled labour rises unambiguously from $D$ to $C$ as $P x / P y$ falls, implying that the real wage of unskilled labour rises with the rise of the price of the good $(Y)$ that uses unskilled labour intensively.

Since, under autarky, production must equal consumption, the range DC 


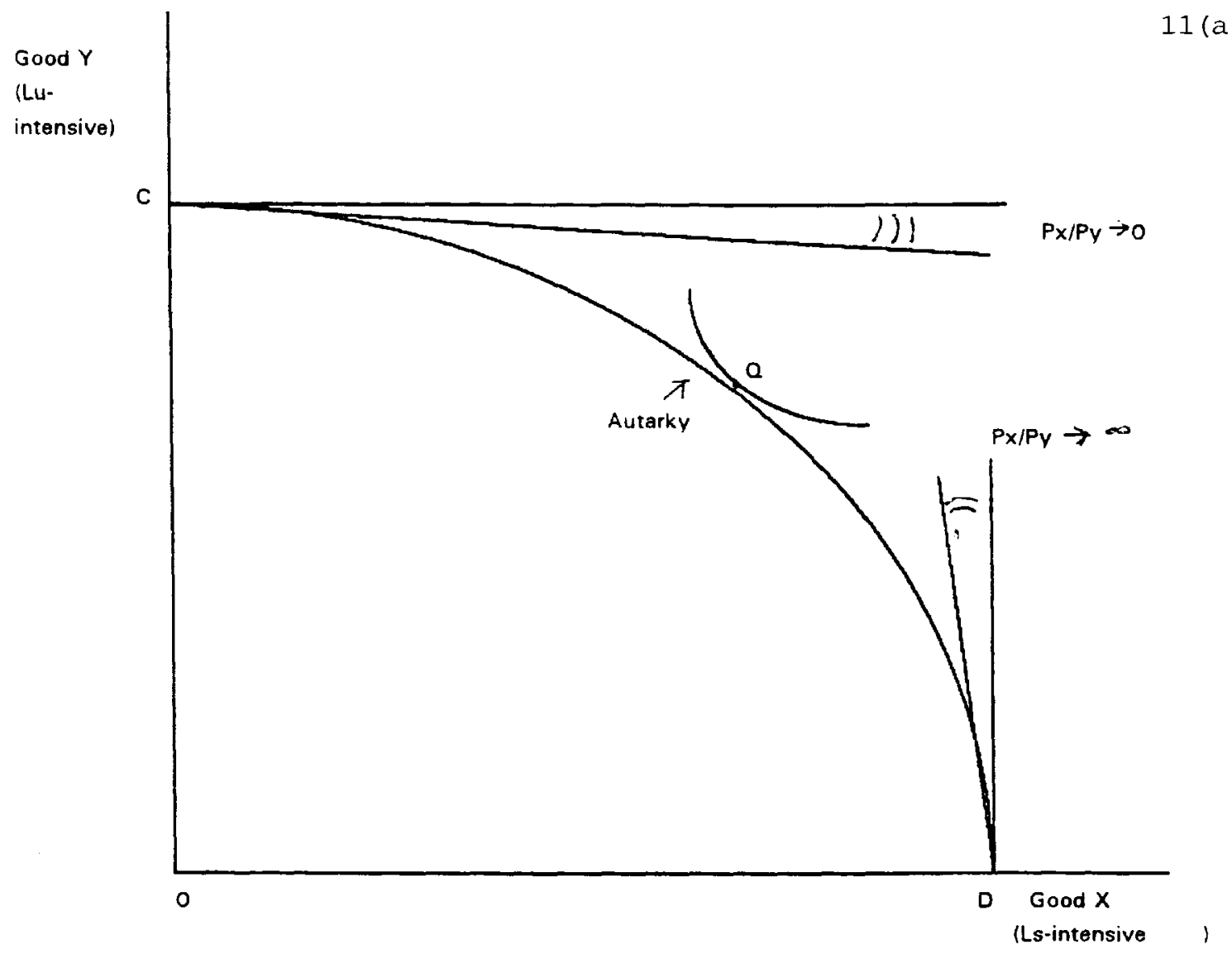

FIGURE 5 
defines all the real-wage variations that are possible under autarky. So, as depicted in Figure 6, ECQDR is the thick-lined curve linking the real wage of unskilled labour to alternative goods price-ratios under autarky. The real wage does not change, once complete specialization is reached at $C$ and at $D$ : further variations in Px/Py leave production specialized at these points, at maximum levels feasible.

Next, under free trade, production is no longer equal to consumption. Therefore it is now possible to specialize in production at $D$ and at $C$ and to trade from there at $P_{x} / P_{y}$ higher than $D S$ and below $C V$ respectively ${ }^{15}$ Correspondingly, the real wage will now improve for (both factors and therefore) unskilled labour at both $D$ and $C$ as $P x / P y$ varies further. The free-trade curve in Figure 6 therefore is $\mathrm{ZCDH}$.

If follows then that:

* $C D$ is the range over which the conventional Stolper-Samuelson redistributive effect, leading to a fall in the real wage of one factor and a rise in that of the other factor, operates;

* the real wage of unskilled labour will fall (in Figure 6) from equilibrium production in autarky at $Q$ when free trade reduces the relative price of good $Y$ which uses the unskilled labour intensively (i.e. Px/Py rises); this fall in real wage will continue as Px/Py rises upto when specialization in Ls-intensive good $X$ emerges at $D$; but

* for Px/Py improving beyond that, the real wage of unskilled labour will bounce back, improving upto $G=(Q)$ and then beyond to improvement over autarky and even to $F(=C)$ and even beyond to levels which exceed the best real wage

\footnotetext{
${ }^{15} \mathrm{DS}$ is the goods price ratio tangent to the production possibility curve $C D$ at $D$ and hence is the minimum price ratio $\mathrm{Px} / \mathrm{Py}$ at which the economy reaches specialization on good $\mathrm{X}$. Similarly, CV is the maximum price ratio Px/Py at which the economy specializes on good $\mathrm{Y}$.
} 


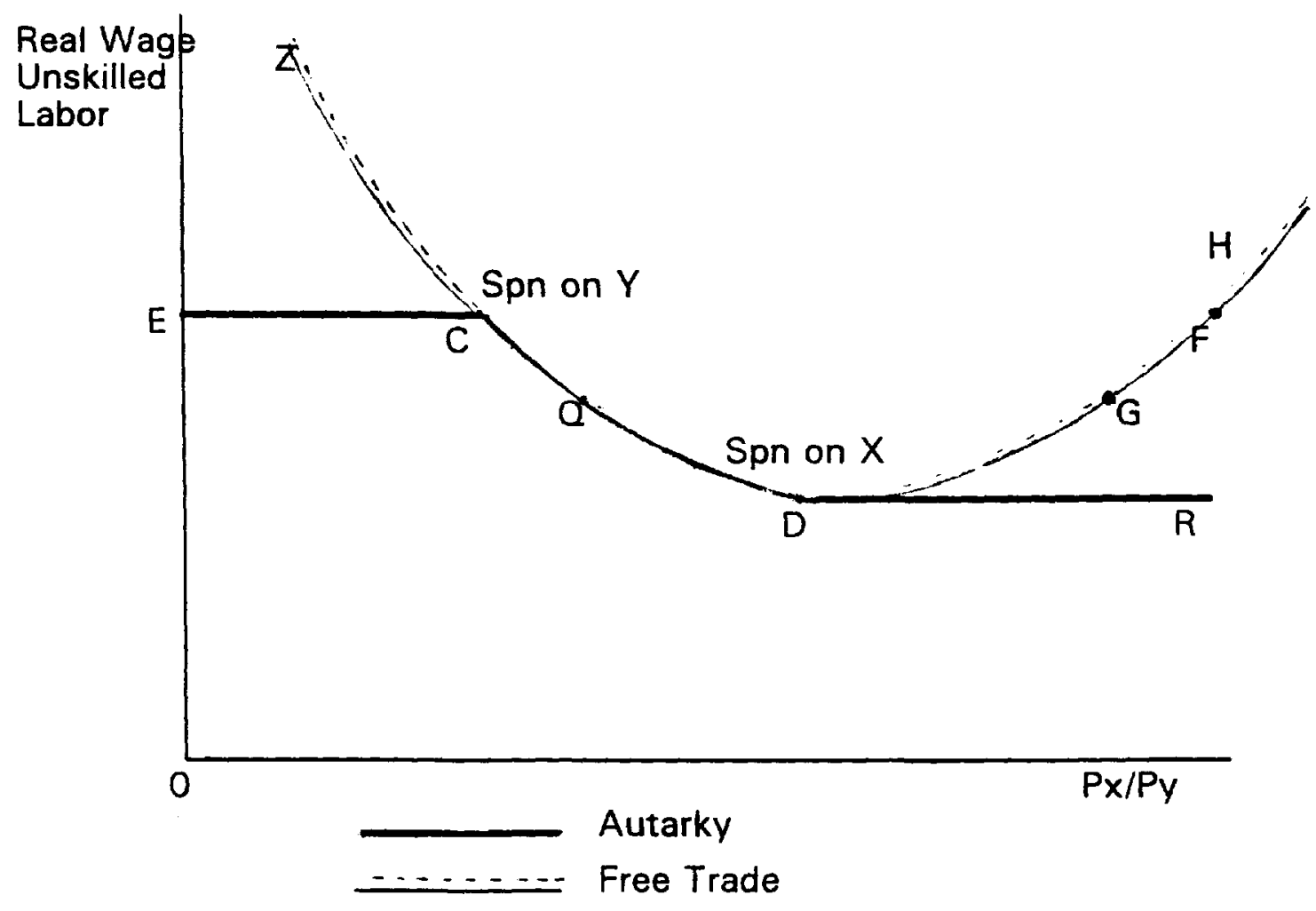

FIGURE 6 
achievable under autarky.

If we are indeed in this ball park, in ranges of real wages along DGFH in Figure 6 that obtain when complete specialization on $Y$, and away from $X$, has been reached, then of course it becomes critical to know what the consumption patterns are. I.e., as terms of trade continue to improve beyond what brings about specialization in production in the $2 \times 2$ model, both factors will benefit but their benefit will depend on how much of the other good they consume (with no benefit for a factor in the extreme case where nothing of the other good is consumed by that factor). In this regard, it is important to note that several studies such as William Cline's (1990) on textiles show that the lower-income groups are pretty intensive in their consumption of imported, unskilled-labour-intensive goods, so that the adverse Stolper-Samuelson effect is that much more likely to be swamped by the lifting-all-boats effect at issue.

* Equally, scale economies can overturn the redistributive effect, improving the real wages of both factors. Panagariya (1985) demonstrated this first, using the conventional model where perfect competition is allowed to continue. Helpman and Krugman (1993) then demonstrated the result when scale economies lead to imperfect competition. Then, Brown, Deardorff and Stern (1993) noted that the Helpman-Krugman result was under the special case where the output per firm did not change with trade and extended the analysis to the more general case where this is not so. ${ }^{16}$

I am known for my skepticism about the empirical importance of scale economies and could be properly chided if I show warmth towards them when they

\footnotetext{
${ }^{16}$ These authors have a fuller analysis of the effects of scale economies on factor rewards than the single point that I have highlighted. They have also used the Michigan CGE model, as applied to US-Mexico trade, incorporating the scale effects, and argued that the real wages in the US will in fact rise, not fall, as a result of freeing trade with Mexico.
} 
produce results that I would like to see! But, the Panagariya-Helpman-Krugman reminders are important in the present context for those who think that scale economies are truly significant in thinking about the real world.

* Then again, there could be lifting-all-boats effects from more competition and discipline resulting from the freeing of trade, causing $X$-efficiency effects which may be formally modelled as Hicks-neutral technical change. If we do this, and if we assume that the effect operates throughout the economy, in both traded sectors in a $2 \times 2$ model, then clearly both factors get their real wages improving from this cause, countervailing and possibly reversing the fall in the real wage of the Stolper-Samuelson-effect-impacted factor. Evidently, the argument can be extended to the case where the Hicks-neutral technical change is differentially greater in the import-competing sector and, with suitable assumptions, to biased technical change as well.

The empirical evidence on this hypothesis is hard to find. However, Levinsohn's (1993) ingenious work on the imports-as-competition hypothesis, while not quite in the form suggested here, is successful in testing that hypothesis with the use of Turkish industry data under ideal, near-controlled-experiment conditions. More work needs to be done to make this argument empirically more compelling.

Five further comments are in order, however.

(1) Though the observed goods prices do not conform to the StolperSamuelson thesis, the quantity-of-imports studies, such as the careful and detailed work of Adrian Wood (1994), suggest otherwise: imports of unskilled-labourintensive goods have certainly increased and such increases have been associated with the fall in real wages. However, the intermediation via price fall 
cannot be avoided. This is readily seen through Figure 7 where Apparel imports, increasing due to increased domestic demand, leave both the price and domestic production unchanged and hence could not affect the wage of the unskilled in Apparel manufacture.

This argument becomes critical in entertaining skepticism concerning, if not rejecting, also the Borjas-Ramey (1994) argument that the growth of imports has led to the decline in the wages of the unskilled. They show that there is a tight timeseries relationship between imports as a share of GDP and the skilled-wage differential (rather than the real wage of the unskilled): note that there is no data here on relative goods prices. But in general-equilibrium analysis, it is easy to show that both the correlated phenomena may be a result of, say, technical change (the explanation that seems much the more likely to many). ${ }^{17}$

To see this, consider Figure 8. If Hicks-neutral technical change (i.e. isoquants are uniformly renumbered upwards) is in the skilled-labour-intensive good, Machinery, it will lead to a disproportionate increase in the output of Machinery, indeed even in a decline in output of the other unskilled-labourintensive good, Apparel (this being the wellknown Rybczynski (1955) effect): i.e. in Figure 8 , the output will shift from $P$ to $P^{\prime}$, not $P^{n}$. If there is no reason to expect the income-elasticity of demand for the two goods to be significantly different from unity (i.e. for consumption to shift from $C$ to a point substantially different from $C$ ' along $\left.C^{\prime} P^{\prime}\right)$, then the net effect will surely be to increase imports (and trade) as a proportion of GNP as the economy grows due to the technical change..$^{18}$

Equally, one can show that the Hicks-neutral technical change in Machinery

\footnotetext{
${ }^{17}$ Indeed, for the specific configuration of technical change and factor-intensity conditions modelled below, such correlation is inevitable, not just a possibility.

${ }^{18}$ Note that the increased demand is not being arbitrarily introduced into the analysis; it is intrinsic to the analysis of technical change as such change increases income.
} 


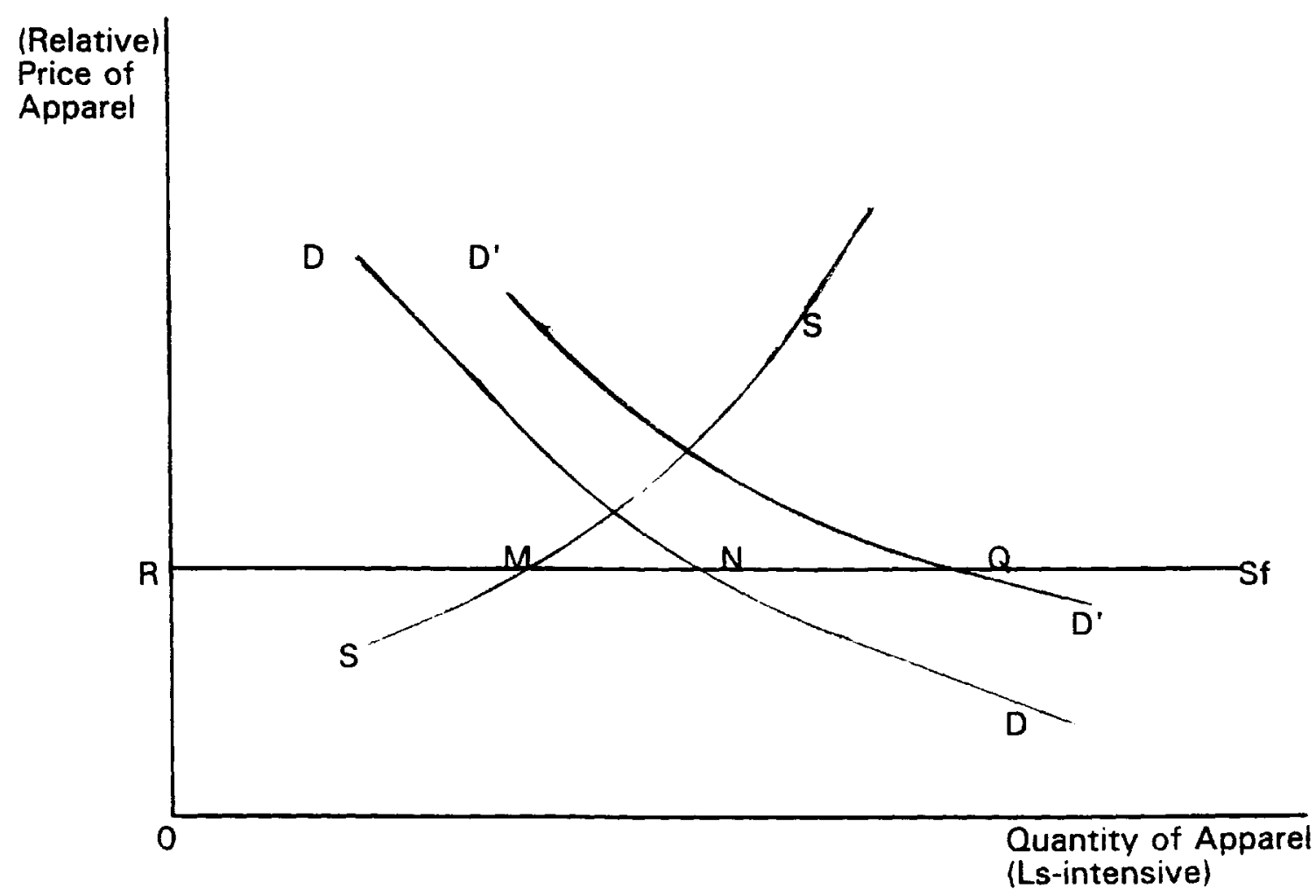

FIGURE 7 
15 (b)

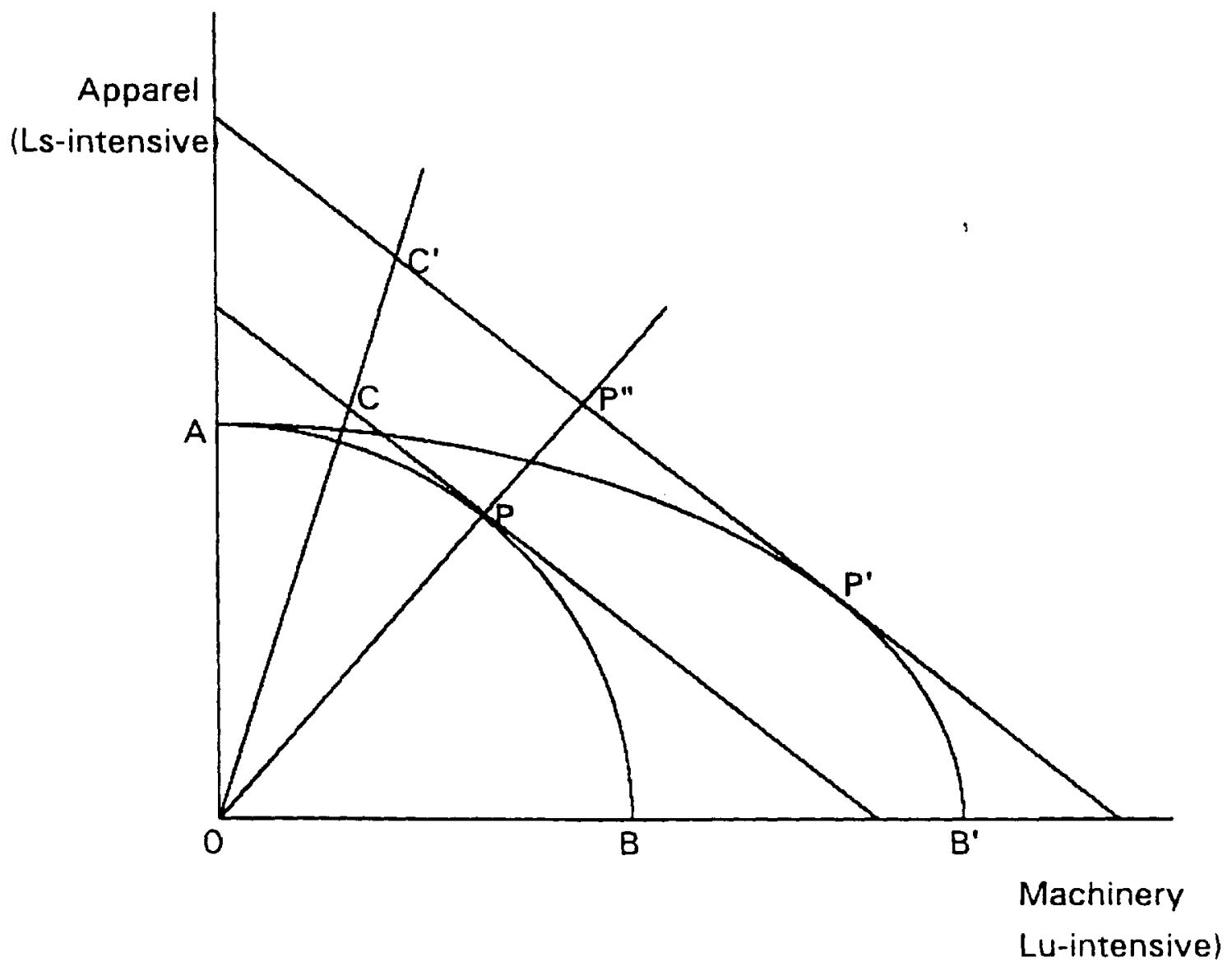

FIGURE 8 
will increase the relative wage of skilled labour since it will disproportionately increase the demand for skilled labour in which it is intensive. Figure 9 shows this, using the wellknown Findlay-Grubert (1959) diagram. Given the goods price-ratio exchanging $A$ for $M$, we can take the tangent $Q R$ to these two isoquants and that yields the associated factor price-ratio. When Hicks-neutral technical change occurs in Machinery, the same $M$ can be produced by less factors, shifting $M$ down to $M^{\prime}$. the new factor price-ratio $Q^{\prime} R^{\prime}$, consistent with the same goods price-ratio $(A / M)$, is then yielded by the tangent to $A$ and $M^{\prime}$. Q'R' relative to $Q R$ then shows a rise in the relative wage of skilled labour. Thus, both the variables, the skilled wage differential and imports as a share of GNP, will move up with (relatively greater) technical change in the skilled-labour-intensive industries, and this will happen at unchanging relative goods prices.

Indeed, it is worth noting that the technical-change explanation also fits better the observed changes in factor proportions in the United States, as noted by Lawrence and Slaughter (1993). Nearly everywhere, the proportion of skilled to unskilled labour has risen, not fallen; but that is exactly the opposite of what we would expect if the driving force in the real wage decline had been a trade-induced decline in the price of unskilled-labour-intensive importables, and is what we would expect if technical change in the skilled-labour-using industries, and also skilledlabour-using technical change, were the source of the change. ${ }^{19}$

Thus, I find it difficult to accept the argument, often advanced by Adrian

\footnotetext{
${ }^{10}$ Indeed, the claim that a dramatic onrush of unskilled-labour-saving technical change is behind the disturbing phenomenon of declining unskilled wages is backed by other evidence and analyses which are reviewed in Bhagwati and Dehejia (1994). This article also considers the added, "gloom and doom" argument that the underlying production functions in different industries may be characterized by capital-skills complementarity, as originally investigated by Zvi Griliches, and that even capital accumulation may then lead to falling real wages of those without skills. And, if technical change accentuates that kind of complementarity, as it seems to do, the prospects of either technical change or capital accumulation offering significant improvement to the unskilled workers begins to dim greatly.
} 
$16(a)$

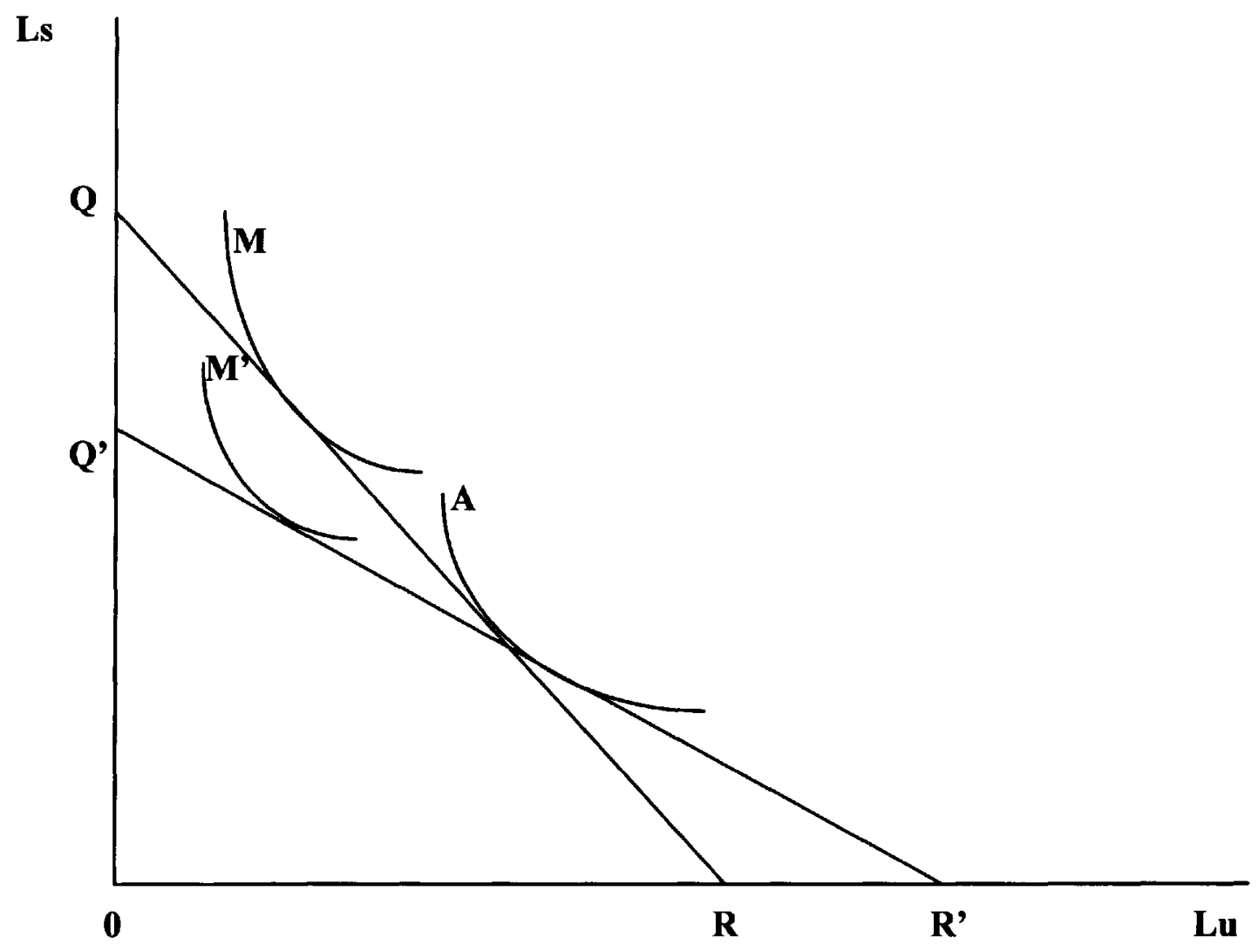

FIGURE 9 
Wood, that almost all "quantity" data point towards trade as the source of the problem and that it is only "prices" that do not conform. First, to say that is to say that, in a production of Hamlet, only the Prince was missing, all else was fine! Second, as I have just explained, even the non-price "quantities" such as import ratios are consistent with a nontrade explanation whereas "quantities" such as factor proportion changes are more consonant with the technical-change explanation.

(2) Let me then turn to the question: why have the domestic goods prices of labor-intensive goods not fallen during the 1980s? Let me offer two alternative explanations, and then draw implications therefrom for the issue at hand.

Explanation 1: One major explanation is that, even though the prices of unskilled-labour-intensive goods would have fallen as the pessimists fear, the VERs on textiles, shoes etc., and the anti-dumping actions against several other products that broke out in the early 1980s, would have implied export restraints that would translate into an effective (countervailing) rise in c.i.f. landed prices and hence in US domestic prices as well, of course.

Textile trade experts note that the Asian competition in textiles and apparel broke out seriously during the latter half of 1970 s but that its effects on domestic adjustment were substantially mitigated by the swift response of the industry in tightening the Multi-fibre Agreement's restrictiveness. Indeed, it is wellknown that administered protection (consisting of anti-dumping actions, VERs, and a variety of export-restraining arrangements between governments) broke out for sure in the first half of the 1980s in the United States and Europe. The restrictiveness of trade barriers may therefore have generally increased, offsetting the Stolper-Samuelson effect by selectively moderating the goods price effect, as necessary, in the first 
place (as the price data of Lawrence et.al. indicate). Such elasticity and also selectivity are in fact a characteristic of the "administered" protection as embodied in anti-dumping actions, VERs etc. and make them both a preferred instrument of protection by industry and also a more serious hazard to free trade than conventional protection. ${ }^{20}$

Explanation 2: An alternative explanation is that the developing-countrytrade-induced decline in the relative price of unskilled-labour-intensive goods was more than offset by the technological-change-induced decline in the prices of US exportables. This effect may be even more substantial than would appear from unadjusted price data because quality changes are also likely to be far greater in technologically progressive, "Schumpeterian" industries, and they should appear disproportionately in US exports than in US imports: a fact noted in the 1950 s by Irving Kravis (1956) and then documented and analyzed by many in the 1960 s.

In short, one could then argue, in the former case, that the trade-induced pressure on labour-intensive goods prices was offset by countervailing administered protection; and, in the latter case, that it was overwhelmed by the effects on goods prices of technical change. The domestic goods price change that one observes is the gross price change, a result of several factors, whereas what we truly need is the net price change attributable to the alleged trade factor. Estimating the latter in a properly-specified model which can net out the effects of

\footnotetext{
${ }^{20}$ The fact that world, not just domestic, prices of unskilled-labour-intensive goods have increased instead of falling suggests that the VER explanation may be relevant: VERs may be expected to raise the export prices by the amount of the rents.
} 
the other factors is what is required but is not currently available. ${ }^{2 t}$ What we do know for now is that the observed, gross price change is not supportive of the fears of the trade-and-wages pessimists. And that does cripple the case advanced by these pessimists for now.

(3) What does all this say about future prospects? The typical worry that is often voiced is: when "big" poor countries such as China and India come on board with their trade expansion due to domestic growth and/or their trade liberalization, all hell will break loose, pushing the prices of labour-intensive goods down to low levels and crushing the real wages of our unskilled in consequence.

Now, if the reason why the domestic prices of unskilled-labour-intensive goods here did not fall during the 1980s was the compensating growth of administered protection --- a possibility that I suggested for investigation above ---, this would not be reassuring: for, it would mean that trade did not hurt real wages because protection prevented it from doing so by offsetting the fall in goods prices that trade would have induced. That is surely no argument for being free from worry on the income distributional effects of trade if protectionist responses are to be ruled out!

But, we can easily exaggerate the pressure on the prices of unskilledlabour-intensive goods from poor countries' trade liberalization, or from the expansion of their' trade at any given level of their trade barriers, and the adverse effect thence on real wages of the unskilled in the rich countries.

\footnotetext{
${ }^{21}$ One "stylized" way to do it might be as follows. Assume for simplicity that the goods price changes are exogenous to the US, and come from trade-induced factors. Calculate the corresponding effects on real wage of unskilled labour a la Stolper-Samuelson. Attribute the difference between this calculated "trade" effect on real wages and the actual, observed real wage change as that to be attributed to "domestic" factors such as technical change. That in turn could be done by regressing the estimated difference against estimated Total Factor Productivity change, accumulation of labour relative to capital etc.
} 
Thus, in regard to effects on goods prices, the focus on the expansion (in formal terms, as in Figures 2 and 3) ) of the offer curve from the poor countries is misleading. For, it forgets that the offer curve of the rich countries will also be expanding. Given the fact that the poor countries' national incomes add upto only a small fraction of the national incomes of the rich countries, and that the averages of the trade-to-GNP ratios between the two groups are not much apart, the net demand for the unskilled-labour-intensive exports of the poor countries may well rise, instead of falling. ${ }^{22}$

But even if prices were to fall for imported unskilled-labour-intensive goods in the next decade, recall that it is by no means inevitable that this will translate into a fall, rather than a rise, in the real wages of the unskilled in the OECD countries. I have already recounted several reasons, implicit and explicit in the Stolper and Samuelson paper, why all factors of production can gain from the fall in import prices and the associated trade expansion that trade with the South may bring. And these reasons are not at all unrealistic, as I have already indicated. It is then simply a fallacy to think that the hand of Stolper-Samuelson theorem is an iron fist aimed at the real wages of our unskilled workers.

(4) It is perhaps worth noting also that the adverse effect on the real wages of the unskilled, if any, will increase with the decline in the prices of the unskilledlabour-intensive goods. But so will the gains from trade increase as the improvement in the terms of trade becomes greater. The latter would increase our income further yet and thus, ceteris paribus, lead to more revenue at any given tax rates. This should correspondingly ease the constraints on spending to relieve the

\footnotetext{
${ }^{22}$ Of course, one could argue that, if the offer curve of the developing countries had not shifted outwards, our own net growth of demand for imports would have resulted in a greater rise in the price of the unskilled-labour-intensive importables and hence in the real wages of our unskilled labour over the 1980 s. This may be the only real kernel of valid argument going for those who contend that trade has "hurt" our workers, ceteris paribus.
} 
increased trade-determined distress to the unskilled. Thus, we have a built-in stabilizer in terms of reduced revenue constraints as the impact on real wages of the unskilled rises (if at all) if trade with the South drives down the real wages of the unskilled.

(5) But whether one is a pessimist or an optimist (as I am) on the issue at hand, agreement on one policy option seems possible. Both could unite in support of policy programs to limit the growth of population (and hence of unskilled workers) in the large, poor countries. The optimists will support such programs simply because they are desirable for large and poor countries such as India and China, and this is also the considered view of these countries' policymakers, as evident from the Cairo Conference on Population last summer.

But the pessimists should support population control programs, in our own interest. It is easy to see why.For, if immigration, which directly brings the unskilled aliens from the poor countries into our midst, cannot be totally controlled by us and borders often tend to get beyond control (as at Rio Grande) because our political traditions prevent us from shooting at illegal immigrants coming across borders, and if trade is also feared by the pessimists to be simply an indirect way of letting in such alien labour, both phenomena then amounting to pressure on the real wages of our unskilled, then the situation is fairly grim, especially if the decline of the political ability to redistribute prevents us from compensating for the decline in real wages of our unskilled ${ }^{23}$. In that case, the pessimists can only hope for lower pressures from the unskilled abroad: and this implies our assistance in acceleration of their capital accumulation, on the one hand, and in effective

\footnotetext{
${ }^{23}$ The parallel between trade and immigration as indirect and direct ways of affecting real wages in the same direction was at the heart of the political debate on the first-ever-anywhere national immigration legislation, enacted in the U.K. in 1905. At the time, free traders were free immigrationists whereas the protectionists were anti-immigrationists; and free immigration was described as "free trade in paupers". See Bhagwati (1991a) for details and an analysis.
} 
control of their population growth, on the other.

The shift from the Bush administration's more complacent attitudes on population control, prompted largely by the religious right, to the Clinton administration's energetic support of effective population policies at Cairo, prompted partly by liberal views concerning women's rights, can then be explained also as a response (among several) to the fears of the adverse effect of trade with the South on the real wages of our unskilled.

B. "Kaleidoscopic" Comparative Advantage and Higher Labour Turnover: An Alternative Trade Explanation:

My view of the Stolper-Samuelson North-South trade explanation of the decline in the real wage of our unskilled during and since the 1980 s is thus profoundly skeptical, on current evidence. It is so on theoretical grounds as well. ${ }^{24}$

But that is not all that one can say about the possible effect of trade on real wages. Recently, I have suggested (Bhagwati, 1991b), Dehejia (1992a)(1992b) has explored analytically, and Bhagwati and Dehejia(1994) have elaborated, an alternative trade explanation for real wage decline. The explanation, which has nothing to do with the Stolper-Samuelson analytical framework and looks at trade more generally than in a North-South framework, has essentially four parts.

1. Greater internationalization of markets (i.e. rising trade-to-GNP ratios, greater role of transnational corporations in globalizing production), the diffusion of

\footnotetext{
${ }^{24}$ I have concentrated here on several reasons why the Stolper-Samuelson theorem may not obtain. These would generally undermine the Factor Price Equalization theorem as well. Of course, the Stolper-Samuelson effect could obtain in the rich countries even if the Factor Price Equalization theorem did not obtain.
} 
production knowhow within OECD countries (as documented by Baumol, Blackman and Wolff (1989)) and the increased integration of world capital markets (as discussed in Jeffrey Frankel (1994)) have narrowed the margin of comparative advantage enjoyed by many industries in any major OECD country. There are therefore more footloose industries now than ever, leading to greater volatility in comparative advantage, i.e.more "knife-edge" and hence kaleidoscopic comparative advantage, between countries.

2. This will lead to higher labour turnover between industries and hence to more frictional unemployment.

3.Increased labour turnover could flatten the growth profile of earnings due to less skill accumulation.

4. These three factors could also explain an increasing wage differential, ceteris paribus, if skilled workers have greater transferability of workplace-acquired skills than do unskilled workers. ${ }^{25}$

This theory has yet to be investigated. In particular, whether comparative advantage has indeed become "thin", resulting in the kaleidoscope effect (element 1), has not been documented empirically. ${ }^{26}$ I might add that there is some suggestive evidence on (elements 3 and 4 of) the explanation above in labour studies, as noted in Bhagwati and Dehejia (1994), and also in Lisa Lynch's (1995) recent work.

\footnotetext{
${ }^{25}$ As for increased differential in favour of the skilled workers, increased turnover could explain that additionally if we were to argue that the search period between jobs is more likely to be used by the skilled to add to their skills through study than by the unskilled. Once you have been trained and "socialized" to train, it is easier to find the motivation to retool and retrain; if you have never been socialized to train in the first place, you may turn more readily into a couch potato watching TV during fallow periods.

${ }^{26}$ My former Columbia student, Don Davis, now of Harvard University, tells me that he plans to explore this question, using some of the existing literature on changes in "product-line" specialization of firms. The theoretical exploration of the concept of knife-edge, kaleidoscopic comparative advantage, especially the conditions under which it is accentuated by globalization, is also necessary.
} 
The evidence on element 2 , concerning higher labour turnover, has undergone however a flip flop, but fortunately for the Bhagwati-Dehejia argument, is presently in favour of their hypothesis that labour turnover rates have increased in the 1980s. Whereas the early thinking was that such turnover had indeed

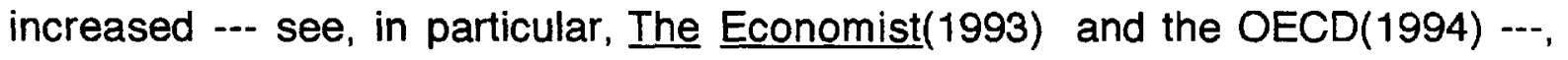
later studies suggested otherwise. Thus, as Bill Dickens notes in his Comment (this volume), recent US data from the Population Survey show that the percent of men with current employer for less than a year has not fallen in the 1980s. Similarly, he argues that the Department of Labor data on the Reallocation of Employment between Industries seems to show no upward trend (though the Bhagwati-Dehejia thesis would survive if there was increased turnover within industries as well). Similar conclusions seem to have been drawn by Diebold, Neumark and Polsky (1994) and Henry Farber (1995).

On the other hand, the recent findings of Stephen Rose(1993), and the related findings of the National Commission for Employment Policy (Rose (1994)(1995)), an independent Commission set up under the Job Training Partnership Act as an independent advisory body reporting to both the President and the Congress, have utilized more-pertinent longitudinal data to argue the opposite. In short, the Bhagwati-Dehejia thesis is back in the picture for now, as far as the turnover hypothesis is concerned.

\section{Rents, Unionization et.al.}

The above arguments are economywide trade explanations. But there are industry-specific trade explanations, of course, of what happens to industries affected by import competition.

Where these are competitive industries, clearly the earnings of the 
productive factors within them will be reduced at the outset. When the industry is wiped out, these earnings will go to zero, of course. The overall, final effect on real wages of these factors including the unskilled, however, cannot be determined without finding out the general-equilibrium implications of the parametric change, which will take into account, for instance, the absorption of the displaced factors elsewhere in the economy, which means going back to the economywide explanation.

What does the presence of unions, and hence of rents to the unskilled in the unionized sectors, do for the argument?There are indeed models of several kinds of imperfect competition in factor markets in the general-equilibrium analysis of international trade which could be extended to address the question of the overall impact of changing goods prices on real wages. But the answers can be quite unexpected. E.g. if unions maintain a wage differential between homogeneous insiders and outsiders, the conventional inferences such as that a fall in the relative price of the unionized-sector's good will lead to a fall in its relative production, and therefore presumably a fall in the unionized factor intensively used in it, will not necessarily hold, undermining the Stolper-Samuelson-type argument (inferring factor reward changes from goods price changes). ${ }^{2}$ To my knowledge, there is no analysis of the effects of price declines in unionized industries such as autos that satisfactorily addresses these deeper analytical issues that arise when the effects of unions are considered in an analytically appropriate fashion.

Then again, we know that, during the 1980s, the "big" unionized sectors in the US, especially autos and steel, were politically powerful enough to shield themselves significantly through anti-dumping actions and VERs, OMAs etc. from the effects of foreign competition (which incidentally was overwhelmingly from the North, not the South). Given both the small percentage of the US unskilled labour force in unionized manufacturing sectors even at that time, and the substantial cushioning of competition through trade restraints in any event, it is highly unlikely that the analysts can demonstrate (through this route) a significant overall role for

\footnotetext{
${ }^{27}$ There is, in fact, a considerable literature on this subject, with contributions by Steve Magee, Murray Kemp, Jagdish Bhagwati and T.N.Srinivasan, Ronald Findlay, Ronald Jones etc. in the 1970s. See the literature review in the graduate textbook, Bhagwati and Srinivasan (1983, Chapter ) which explains why the responses of outputs, for example, to goods price changes may not be "normal" in the presence of such factor market imperfections.
} 
trade in affecting real wages in the US during the $1980 \mathrm{~s}^{28}$

\section{The Question of International Capital Mobility: Globalization and Real Wages}

So far, I have considered only the question of a direct link between trade and real wages. But there are fears of an adverse impact on real wages of the unskilled that follow from fears arising from international capital mobility.

* Thus, a major worry of the unions is that the outflow of capital drives down real wages of unskilled labour. However, during the 1980s, in the US, more DFI (direct foreign investment) came in than went out, both during the period and relative to 1950s and 1960s. Moreover, the US ran a current account deficit so that foreign savings came in, if that is the measure one wants to work with instead. The facts are therefore against that hypothesis.

* But again, if one uses a bargaining-type framework, it might be said that the bargaining power of employers has increased vis-a-vis that of employees because employers can increasingly say in a global economy that they will pack up bags and leave and therefore, for any given output, its distribution between Lu income and other income including profits may have shifted against Lu.

To my knowledge, systematic empirical evidence for such a bargaining model as a determinant of relative rewards between factors within any US industry is not available. Nor do we know whether, for any of these industries, there is evidence of an international relocation elsewhere of part of its local production having altered distribution against Lu income. ${ }^{29}$

At a time when total union membership is down to roughly $12 \%$ of US private employment, however, I doubt if this explanation is likely to be important in any event, unless of course the decline in unionism is itself attributed in a significant measure (as it probably cannot be) to the loss of bargaining power due to the threat of exit by firms to other countries.

\footnotetext{
${ }^{28}$ For a complementary discussion of rents, citing the broader literature on the subject which includes efficiency-wage arguments, see Bhagwati and Dehejia (1994).

${ }^{29}$ The threat of exit may exist, of course, even if no exit has actually occurred in the industry.
} 


\section{Static versus Dynamic Effects}

My analysis of different approaches to the question of the link between trade and wages would not be complete without reference to the growth or dynamic effects that trade can have on wages by affecting several different "fundamentals" such as the rate of accumulation and technical change.

If indeed technical change or accumulation is agreeably affected, even as the initial static effect on real wages is adverse, the overall effect in the long run could swamp the static effect. The effect of trade on X-efficiency via competition, as discussed in Section II.1 (in reference to Levinsohn's recent work), suggests for example that if this effect operates continuously and is not a once-time effect, it would certainly help to improve growth rates and hence to pull up real wages over time.

This is a matter of importance since we will have to make up our minds as to how trade, in specific parametric cases, interacts with growth and how this in turn affects real wages of the unskilled. Evidently, the Far Eastern countries, whose rapid growth rates of capital and income since the 1950s cannot be delinked from their outward orientation in trade $e^{30}$, did pretty well in regard to their real wages, outweighing any static adverse effect that the importation of unskilled-laboursaving technology may have had on real wages in the short run.

Our problem today may then well be that, with our growth rates rather low (whether exogenously or endogenously to trade), we are unable to outweigh the drag on real wages that is being provided by either trade (which I doubt) or by technology (which I suspect is the true and overwhelming cause of the problem).

\section{Concluding Thoughts}

\footnotetext{
${ }^{30}$ In considering trade to have been a significant engine of the Far Eastern miracle, I find myself in disagreement with Paul Krugman (1994) who denies that there was a miracle by noting that much o the exceptionally high growth is attributable simply to high rates of capital accumulation. But he forgets that those high rates of accumulation themselves need to be explained: this is where (contrary to Dani Rodrik's recent arguments which I consider to be in error) I consider the outward orientation of their trade policy and its role in creating and sustaining very high incentives to invest to have been critical. Besides, the tremendously high private rates of accumulation are indeed, by conventional standards, a "miracle" i.e. hugely off the curve.
} 
My analysis leads me to conclude optimistically about the effect of freer trade on the real wages of the unskilled in the rich countries. The evidence for the NorthSouth (Stolper-Samuelson) argument is thin, at best. The evidence for the NorthNorth (Bhagwati-Dehejia) argument is, on current indications, equally thin. To date, there is no compelling evidence for the capital-mobility-cum-bargaining model either. The big-ticket weapons in the war chest of the pessimists are therefore without firepower.

Yet, the issue remains politically salient just because the linkage seems overwhelmingly intuitive, I am afraid. It will continue to affect policy in several areas, indeed not to our advantage.

Thus, to cite one compelling example, it certainly fuels the push for including labour standards into the WTO since the objective of the unions that provide the main political force for such inclusion in a Social Clause is precisely to raise in any way they can the cost of production of their rivals in the poor countries. This issue is dividing the rich and the poor countries. It is also an issue where I fear that the current US position lacks probity and statesmanship and appears instead to be a prisoner of lobby-led special-interest politics. ${ }^{31}$

In turn, I have no doubt that it is a principal reason for the infatuation of the United States with preferential trading arrangements (PTAs) such as Free Trade Areas even though the WTO has been jumpstarted and we would expect the United States to return to multilateralism. These PTAs between a hegemon and non-hegemons enable the hegemon, and its lobbies pushing for trade-unrelated issues such as intellectual property protection, environmental demands, labour standards demands etc., to extract significant concessions from non-hegemons when the latter are bargained with one-on-one rather than in their greater numbers and strength directly in Geneva. The concessions that President Salinas made on these nontrade issues to the United States were far greater than those available from the poor countries en bloc at Geneva. And now, Chile will have to accept them to get into NAFTA.

\footnotetext{
${ }^{31}$ I have discussed the nuanced objections to a Social Clause in the WTO, and outlined a set of alternative, better ways to promote one's ideas about labour standards, in several recent writings and in TV, radio and other debates with the protagonists of a Social Clause. In particular, I would urge the reader to consult Bhagwati (1995c)(1995d).
} 
The sequential bargaining with non-hegemons, made possible by choosing the PTA route selectively with economically and politically vulnerable nonhegemons rather than exclusively the multilateral mode of trade negotiations with all non-hegemons, enables the hegemon then to extract much more on nontrade issues, what John Whalley has called "side payments" than what the hegemon can extract in the multilateral context directly. The desire to raise the poor countries' costs of production to "manageable" levels by imposing expensive environmental and labour standards on them is then more readily fulfilled if the PTAs are embraced as a strategic bargaining strategy alongside the multilateral negotiations. ${ }^{32}$ And this desire has political salience precisely because of the fear that free trade imperils our real wages (and jobs).

\section{REFERENCES}

Bhagwati, Jagdish, 1964, "The Pure Theory of International Trade: A Survey", Economic Journal, June.

Bhagwati, Jagdish, 1991a, "Free Traders and Free Immigrationists: Strangers or Friends?, Russell Sage Foundation Working Paper No.20, New York.

Bhagwati, Jagdish, 199lb, "Trade and Income Distribution", Paper presented at the Columbia University Conference on Deindustrialization,

${ }^{32}$ The idea of sequential bargaining, and the associated idea of a "selfish hegemon" that pursues therewith an agenda serving its national interest (defined with or without lobbies), has been developed by me in several recent writings. See, in particular, Bhagwati (1994). 
November 15-16, 1991, New York.

Bhagwati, Jagdish, 1994, "Challenges to Free Trade: Old and New", 1993 Harry Johnson Lecture, Economic Journal, March.

Bhagwati, Jagdish, 1995a, "Trade and Wages: Choosing among Alternative Explanations", Federal Reserve Bank of New York Economic Policy Review, January, Vol.1(1).

Bhagwati, Jagdish, 1995b, Free Trade, 'Fairness' and the New Protectionism: Reflection on an Agenda for the World Trade Organization, 1994 Harold Wincott Lecture, Institute for Economic Affairs, London.

Bhagwati, Jagdish, 1995c, "Trade Liberalization and "Fair Trade" Demands: Addressing the Environmental and Labour Standards Issue, The World Economy November.

Bhagwati, Jagdish and Vivek Dehejia, 1994, "'Freer Trade and Wages of the Unskilled --- Is Marx Striking Again?", in Bhagwati and Kosters (ed.), Trade \& Wages, American Enterprise Institute, Washington DC.

Bhagwati, Jagdish and Marvin Kosters (ed.), Trade \& Wages, American Enterprise Institute, Washington D.C.

Bhagwati, Jagdish and T.N.Srinivasan, 1983, Lectures on International Trade MIT Press: Cambridge, Mass.

Borjas, George and Valerie Ramey, 1994, "Time-series Evidence on the Sources of Wage Inequality", American Economic Review.Vol.84, May.

Borjas, George, Richard Freeman and Lawrence Katz, 1992, "On the Labor Market Effects of Immigration and Trade", in G.B.Borjas and R.B.Freeman (eds), The Economic Effects of Immigration in Source and Receiving Countries, Chicago University Press: Chicago, Illinois.

Deardorff, Alan and Dalia Hakura, 1994, "Trade and Wages --- What are the Questions?", in Bhagwati and Kosters (ed.), Trade \& Wages, American Enterprise Institute: Washington DC.

Dehejia, Vivek, 1995, Three Essays on International Trade Ph.D. Dissertation, Columbia University, mimeographed. 
Diebold, Francis, D.Neumark, and D. Polsky, 1994, "Job Stability in the United States", NBER Working Paper No. 4859, Cambridge, Mass.

The Economist, 1993, "Musical Chairs", Economics Focus Column, July 17, 67.

Farber, Henry, 1995, "Are Lifetime Jobs Disappearing? Job Duration in the United States: 1973-1993", Princeton University (Economics department), mimeographed.

Findlay, Ronald and Harry Grubert, 1959, "Factor Intensity, Technological Progress, and the Terms of Trade", Oxford Economic Papers, Vol.11, 111121.

Helpman, Elhanan and Paul Krugman, 1985, Market Structure and Foreign Trade, Cambridge, Mass.:MIT Press.

Kravis, Irving, 1956, "Availability and Other Influences on the Commodity Composition of Trade", Journal of Political Economy, April.

Krugman, Paul, 1994, "The Myth of Asia's Miracle", Foreign Affairs, November/December, 73(6), 62-78.

Lawrence, Robert, 1994, "Trade, Multinationals, \& Labor", NBER Working Paper No. 4838, August.

Lawrence, Robert and Matthew Slaughter, 1993, "Trade and US Wages in the 1980s: Giant Sucking Sound or Small Hiccup?", Brookings Papers on Economic Activity: Microeconomics 2.

Leamer, Ed, 1995, "A Trade Economist's View of U.S. Wages and 'Globalization', Paper presented at the Conference on "Imports, Exports and the American Worker", The Brookings Institution, Washington DC, February 2-3; this volume.

Levinsohn, James, 1993, "testing the Imports-as-Market-Discipline Hypothesis", Journal of International Economics, Vol.35, 1-22.

OECD, 1994, The OECD Jobs Study: Facts, Analysis, Strategies, Paris.

Panagariya, Arvind, 1980, "Variable Returns to Scale in General Equilibrium Theory Once Again", Journal of International Economics, Vol.10, 499-526. 
Rose, Stephen J., 1993, "Declining Family Incomes in the 1980s: New Evidence from Longitudinal Data", Challenge, November-December, 2935.

Rose, Stephen J., 1994, On Shaky Ground: Rising Fears about Incomes and Earnings, National Commission for Employment Policy, Research Report No.94-02, October, Washington D.C.

Rose, Stephen J., 1995, Declining Job Security and the Professionalization of Opportunity, National Commission for Employment Policy, Research Report No.95-04, May, Washington D.C.

Sachs, Jeffrey and Howard Schatz, 1994, "Trade and Jobs in US Manufacturing", Brookings Papers on Economic Activity, 1.

Stolper, Wolfgang and Paul A. Samuelson, 1941, "Protection and Real Wages", Review of Economic Studies, Vol.9(1).

Samuelson, Paul A., 1948, "International Trade and the Equalization of Factor Prices", Economic Journal, Vol.58 (2).

Samuelson, Paul A., 1949, "International Factor-Price Equalization Once Again", Economic Journal, Vol.59.

Wood, Adrian, 1994, North-South Trade, Employment and Inequality, Oxford: Clarendon Press. 


\section{4-1995 Discussion Paper Series \\ Department of Economics \\ Columbia University \\ 1022 International Affairs Bldg. \\ 420 West 118 th Street \\ New York, N.Y., 10027}

The following papers are published in the 1994-95 Columbia University Discussion Paper series which runs from early November to October 31 (Academic Year). Domestic orders for discussion papers are available for purchase at $\$ 8.00$ (US) each and $\$ 140.00$ (US) for the series. Foreign orders cost $\$ 10.00$ (US) for individual paper and $\$ 185.00$ for the series. To order discussion papers, please send your check or money order payable to Department of Economics, Columbia University to the above address. Be sure to include the series number for the paper when you place an order.

708. Trade and Wages: Choosing among Alternative Explanations Jagdish Bhagwati

709. Dynamics of Canadian Welfare Participation

Garrey F. Barret, Michael I. Cragg

710. Much Ado About Nothing? Capital Market Reaction to Changes in Antitrust Precedent concerning Exclusive Territories.

Sherry A. Glied, Randall S. Kroszner

711. The Cost of Diabetes

Matthew Kahn

712. Evidence on Unobserved Polluter Abatement Effort

Matthew E. Kahn

713. The Premium for Skills: Evidence from Mexico

Michael Cragg

714. Measuring the Incentive to be Homeless

Michael Cragg, Mario Epelaum

715. The WTO: What Next?

Jagdish Bhagwati

716. Do Converters Facilitate the Transition to a New Incompatible Technology?

A Dynamic Analysis of Converters

Jay Phil Choi

716A. Shock Therapy and After: Prospects for Russian Reform

Padma Desai

717. Wealth Effects, Distribution and The Theory of Organization

-Andrew F. Newman and Patrick Legros 
718. Trade and the Environment: Does Environmental Diversity Detract from the Case for Free Trade?

-Jagdish Bhagwati and T.N. Srinivasan (Yale Univ)

719. US Trade Policy: Successes and Failures

-Jagdish Bhagwati

720. Distribution of the Disinflation of Prices in 1990-91 Compared with Previous Business Cycles

-Philip Cagan

721. Consequences of Discretion in the Formation of Commodities Policy

-John McLaren

722. The Provision of (Two-Way) Converters in the Transition Process to a New Incompatible Technology

-Jay Pil Choi

723. Globalization, Sovereignty and Democracy

-Jagdish Bhagwati

724. Preemptive R\&D, Rent Dissipation and the "Leverage Theory"

-Jay Pil Choi

725. The WTO's Agenda: Environment and Labour Standards, Competition Policy and the Question of Regionalism

-Jagdish Bhagwati

726. US Trade Policy: The Infatuation with FTAs

-Jagdish Bhagwati

727. Democracy and Development: New Thinking on an Old Question

-Jagdish Bhagwati

728. The AIDS Epidemic and Economic Policy Analysis

-David E. Bloom, Ajay S. Mahal

729. Economics of the Generation and Management of Municipal Solid Waste

-David E. Bloom, David N. Beede

730. Does the AIDS Epidemic Really Threaten Economic Growth?

-David E. Bloom, Ajay S. Mahal

731. Big-City Governments

-Brendan O'Flaherty

732. International Public Opinion on the Environment

-David Bloom 
733. Is an Integrated Regional Labor Market Emerging in the East and Southeast Asia?

-David Bloom, Waseem Noor

734. Migration, Integration and Development

-Abhijit V. Banerjee, Andrew Newman

735. Infrastructure, Human Capital and International Trade

-Ronald Findlay

736. Short Ballots: Why Mayors Are in Charge of So Many Different Things

-Brendan O'Flaherty

737. Demand for Environmental Goods: Evidence from Voting Patterns on California Initiatives -Matthew Kahn and John Matsusaka

738. Inflation and Stabilization in Poland 1990 - 1995

-S.Wellisz

739. Particulate Pollution Trends in the 1980's

-M. Kahn

740. Why has Wage Dispersion Grown in Mexico? Is it the Incidence of Reforms or the Growing Demand for Skills?

-M.I. Cragg and M. Epelbaum

741. Russia's Transition Toward the World Economy:

-P. Desai

742. Poland: Transition and Integration in the World Economy

$-S$. Wellisz

743. Team Effects on Compensation: An Application to Salary Determination in the National Hockey League

-T. Idson and L.H. Kahane

744. Economic Development, Growth of Human Capital, and the Dynamics of theWage Structure -J. Mincer

745. Technology Transfer with Moral Hazard -J.P. Choi (Oct.)

746. Risk Preference Smoothness and the APT

-L.F. Herk, Columbia University, Institute on East Central Europe

747. A Characterization of Cointegration

-P. Dhrymes (Oct.)

748. The Limiting Distribution of the Cointegration Test Static in VAR( $n)$ Models -P. Dhrymes (Oct.) 